\title{
Stab Brain Injury: A Case Report
}

\author{
Amir Kamalifar ${ }^{1 *}$, Firooz Salehpoor ${ }^{2}$, Farhad Mirzaii ${ }^{2}$, Samar Kamalifar ${ }^{3}$ \\ ${ }^{1}$ Department of neurosurgery, Urumia University of medical sciences, Urumia, Iran. \\ ${ }^{2}$ Department of neurosurgery, Tabriz University of medical sciences, Tabriz, Iran. \\ ${ }^{3}$ Student research committee, Arak University of medical sciences, Arak, Iran.
}

*Corresponding Author: Amir kamalifar, Department of neurosurgery, Urumia University of medical sciences, Urumia, Iran. ORCID: 0000-0002-0806-4418.

Received date: July 24, 2021; Accepted date: August 14, 2021; Published date: August 17, 2021

Citation: Amir Kamalifar, Firooz Salehpoor, Farhad Mirzaii, Samar Kamalifar (2021) Stab Brain Injury: A Case Report. J, of Surgical Case Reports and Images. 4(6); DOI:10.31579/2690-1897/086

Copyright: (C) 2021, Amir Kamalifar, This is an open access article distributed under the Creative Commons Attribution License, which permits unrestricted use, distribution, and reproduction in any medium, provided the original work is properly cited.

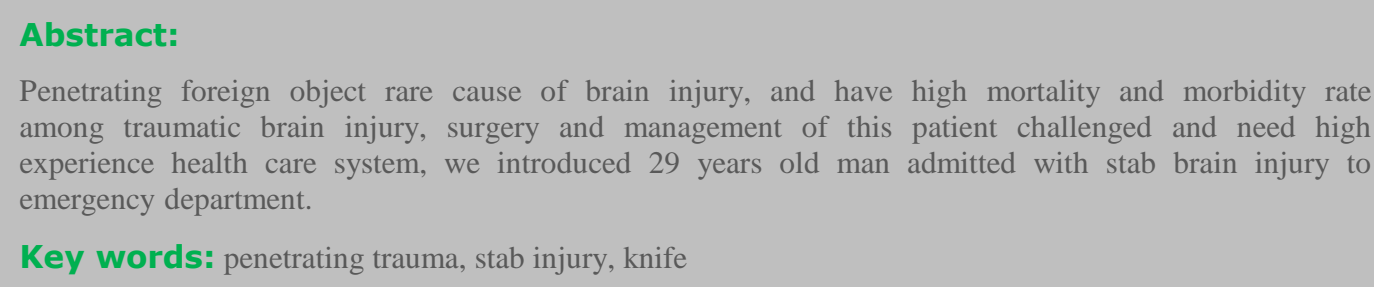

\section{Introduction}

Stab penetrating brain injury is a rare condition of head trauma with high mortality and morbidity rate, [1] severity of injury depend on site and depth of entrance and involvement of major vessel and eloquent cortex, Nevertheless, only few case reports are available describing the management of similar traumatic head injuries [2], we report a 29 years patient with a stab in right frontal.

\section{Case presentation}

A 29 years old man in street fighting crashed with knife stab wound in head region, patient admitted to emergency department of Emam Khomeini hospital Urumia, Iran, with low level of conscious ( $\mathrm{GCS}=4$ ) and knife in right frontal penetrating skull and brain, the position of knife in right frontal $2 \mathrm{~cm}$ lateral to midline and $2.5 \mathrm{~cm}$ anteriorly to coronal suture all blade in cranial and only less than $1 \mathrm{~cm}$ of blade was seen, after resuscitation, $\mathrm{GCS}=4 \mathrm{t}$,intubate without any sedation pupil reactivity poor and vital sign was stable, we take the brain computed tomography (CT) with bon window, CT angiography and skull $\mathrm{X}$ ray also done in emergency room, knife completely penetrate right frontal lobe with micro hemorrhage less than $5 \mathrm{~mm}$ diameter, midline shift and mass lesion not seen, no major vessels involvement not seen, ependymal surface intact not any major sinus disrupted(Figure1-4), patient go under surgery with general anesthesia and island craniotomy was done around the stab and slightly pull up the stab with bone, Dura matter bone and soft tissue around was debrided and irrigated, and sutured patient go under barbiturate coma standard protocols in intensive care unit for 48 hours, follow up CT no evidence any hematoma and mass lesion after 5 day patient slightly awake and then extubated neurological examination was normal all muscle force was normal patient discharged after ten days and control CT 3 week after accident was normal and CT angiography not report any aneurysm, patient advised for follow CT angiography after 3 week and psychological consult but he not get back to our clinic for any follow up.

\section{Discussion}

Traumatic brain injury was major life threatening condition specially stab wound, most patient if survived have major neurological deficit based on severity and location of injury some author emphasis on depth of penetration and type of penetration object [3], head CT scan almost available and highly selected modality to recognize and analyzed various aspect of trauma and can help to planning the surgery [2], preoperative CT angiography also was important to recognize of vessels involvement and situation of them to stab, if any vessel was damaged or involved in rout of entrance surgeon should be consult with vascular surgeon and use vascular bypass or repair technic [4], post operation mostly important, all patient needed antibiotic and anti-epileptic drug at least 10 days and close observation of intracranial hypertension, harsh and wide debridement of brain tissue should be avoided because of iatrogenic neurological deficit [5] but we advised irrigation with large volume of gentamycin reached serum, Removal of the penetrating object should retrace the original trajectory of the knife. During extraction, care must be taken not to produce any rocking movements which may be transmitted to the tip of the knife plan of surgery should be individualized for each patient and sometime need multidisciplinary team [6], all authors 
advised object extraction should be in operation room and attempt to remove of them in emergency make disaster and completely avoid.

\section{Conclusion}

brain stab wound really rare and management of this patient need highly experience team and high tech equipment, multidisciplinary approach mostly can helpful and follow up of patient especially first 6 week most important .
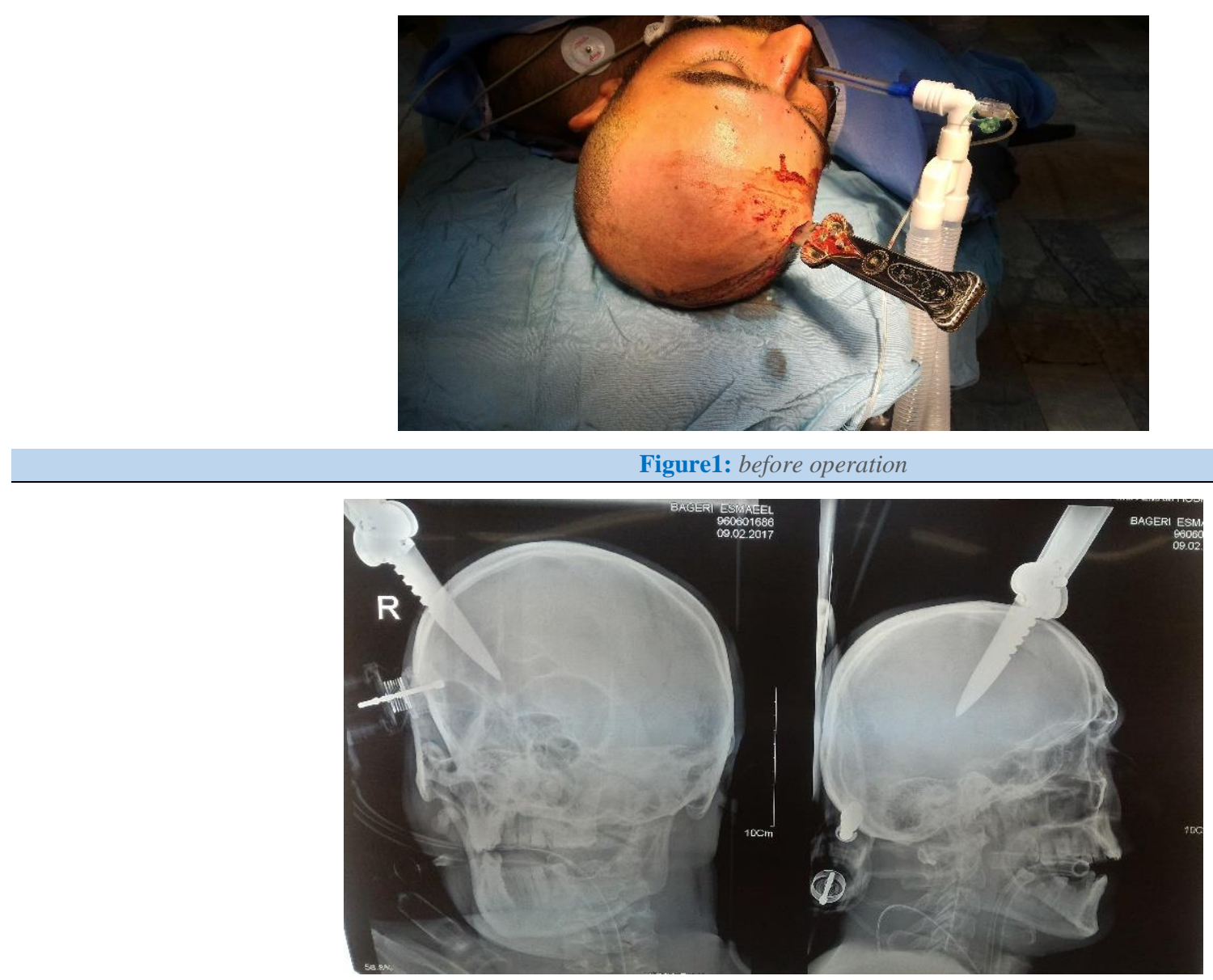

\section{Figure 2: skull X ray: depth of penetration}

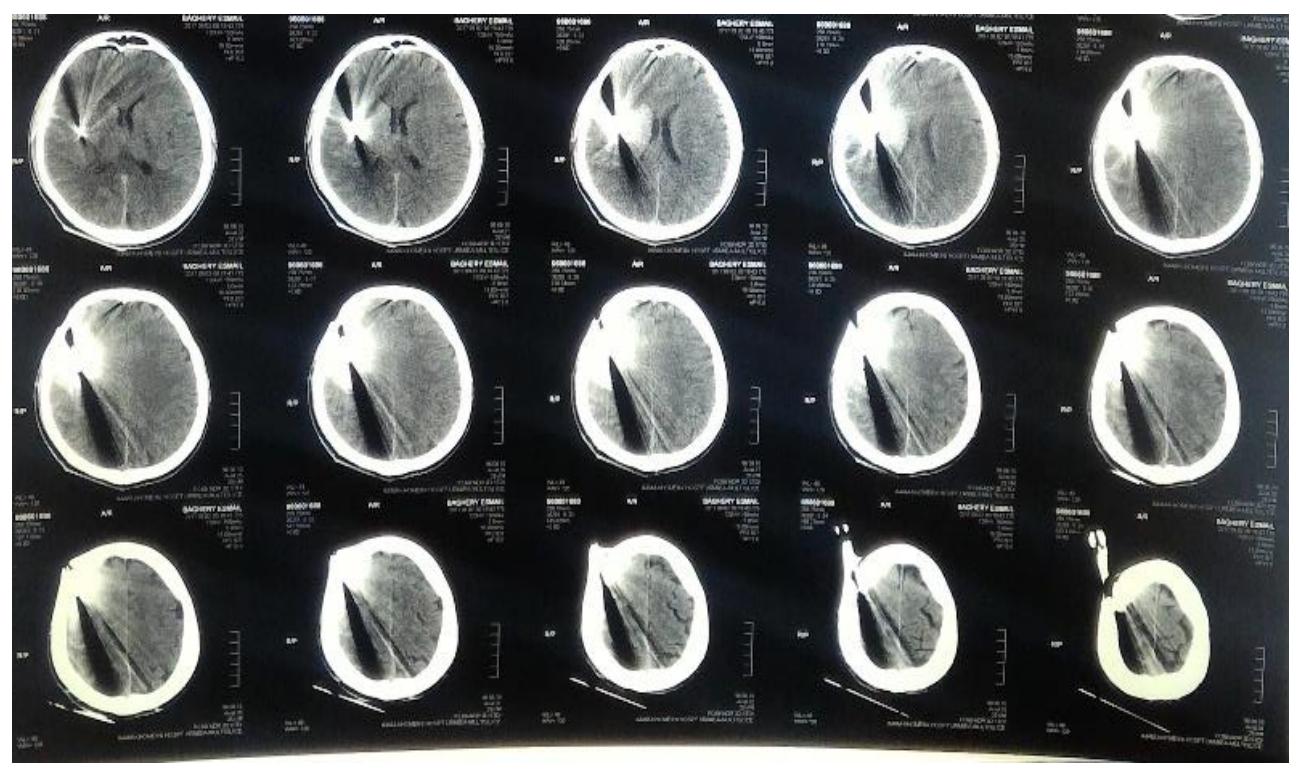

Figure 3: axial brain CT scan entrance and location of the stab 


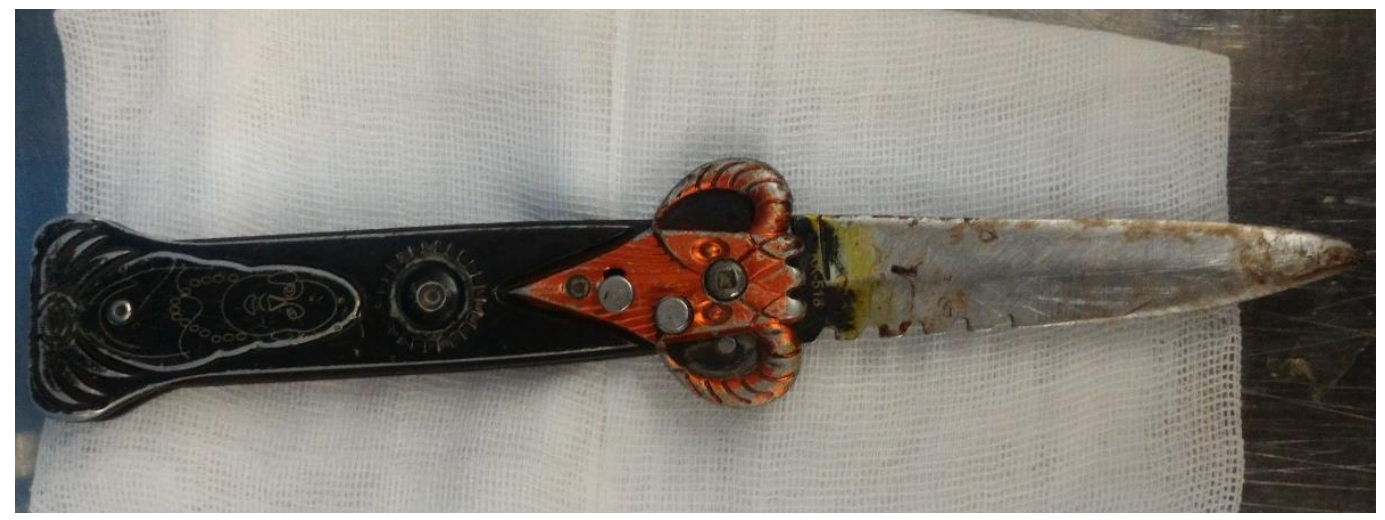

Figure 4: Object after extraction

\section{Reference}

1. Meer, M, Siddiqi, A, Morkel, JA, Janse van Rensburg, P, Zafar, S. (2010) Knife inflicted penetrating injuries of the maxillofacial region: a descriptive, record-based study. Injury. 41(1):77-81.

2. Dempsey, LC, Winestock, DP, Hoff, JT. (1977) Stab wounds of the brain. West J Med. 126(1):1-4.

3. Turbin R.E. (2006) Patterns of transorbital intracranial injury: a review and comparison of occult and non-occult cases. Surv. Ophthalmol. 51(5):449-460
4. Horsfall I. (1999) An assessment of human performance in stabbing. Forensic Sci. Int. 102(2-3):79-89

5. Exadaktylos A.K. (2002) The value of protocol-driven CT scanning in stab wounds to the head. Am. J. Emerg. Med. 20(4):295-297

6. Binitie, O, Shilong, D, Ugwu, B, et al. (2012) Impalement head injury with serrated meat knife. J West Afr Coll Surg. 2(1):67-74.
This work is licensed under Creative Commons Attribution 4.0 License

\section{To Submit Your Article Click Here: Submit Manuscript}

DOI: $10.31579 / 2690-1897 / 086$
Ready to submit your research? Choose Auctores and benefit from:

* fast, convenient online submission

* rigorous peer review by experienced research in your field

* rapid publication on acceptance

* authors retain copyrights

* unique DOI for all articles

* immediate, unrestricted online access

At Auctores, research is always in progress.

Learn more www.auctoresonline.org/journals/journal-of-surgical-casereports-and-images 